\title{
中華人民共和国の医学図書館，情報サービスの実状 (全訳)
}

\section{Biomedical Libraries and Information Services in China}

\author{
傅 菜 (R. T. Frey) ${ }^{1)}$ \\ 訳者 天野 善雄 ${ }^{2}$ \\ 中国医学科学院医学情報研究所 \\ (財) 国際医学情報センター
}

Fu Lai. : Biomedical Libraries and Information Services in China, Igaku Toshokan 30 (1) : 9 - 13, 1983.

The current situation of biomedical libraries and information activities in China is described across-the-board. The Institute of Medical Information of the Chinese Academy of Medical Sciences in Beijing is introduced as an actual national biomedical information center. Biomedical information network activities are reported from the aspects of network development, dissemination of foreign information and staff training. International collaboration activities with WHO, UNDP and the United States for upgrading China's rudimentary system are also introduced. The necessity of developing a strong national biomedical information center and a resource library is emphasized.

\section{I 。はじめに}

中華人民共和国が建設されて以来, 政府は科学技術 情報サービスの開発に多大な関心を払ってきた。1956 年には中国科学技術情報研究所 (Chinese Information Institute of Science and Technology) が設立された。 この研究所は, 中国の国家レベルでの総合情報セン ターにあたる。それ以来, 科学技術情報の研究機関が, 政府や省 (自治区)を含むさまざまなレべルで設置され るようになった。今日では，これらすべての機関が， わが国の工業, 農業, 国防及び科学技術の近代化に大 いに貢献している。

中国の生物医学図書館, 情報システムは, 全国科学 技術情報システムの一構成部分をなしている。その主 要な業務は, 診療, 教育, 研究の発展のために, 全国 規模で医療機関や医療従事者に奉仕すること，及び家 族計画に積極的な援助をすること,である。最近では有 効な情報は，政策決定者や企画立案者にも提供される ようになっている。

1) Dr. Fu Lai : Institute of Medical Information, Chinese Academy of Medical Sciences, Dong Dan San Tiao 9, Beijing, China.

2) Yoshio AMANO : International Medical Information Center 30 Daikyo-cho, Shinjuku-ku, Tokyo 160, Japan.

(昭和 58 年 2 月 4 日 受理)
ほとんどすべての生物医学系図書館は, 医科大学の 中に設置されたものである。それらの多くは，今日の ように医学情報サービスが問題にされる以前に設立さ れたものであり，それぞれかなりの図書を所蔵してい る。生物医学情報サービスそれ自体は比較的新しい活 動分野である。この分野は, 1958 年に従来の図書館と は別個のシステムとして, 新たに加わってきたもので ある。現在では, 中国医学科学院 (Chinese Academy of Medical Sciences)の医学情報研究所 (Institute of Medical Information 略称 IMI) が中国生物医学情報 中心(National Biomedical Information Centre) とし て機能し, WHO 西太平洋地域の生物医学情報計画に おけるフォーカルポイントにも指定されている。更に 省 (自治区) 及び市レベルには 23 の生物医学情報研究 所や事業所があり, 医科大学の中には 56 の主要な生物 医学図書館が存在している。基本的な生物医学情報 ネットワークは, 概ねこのような機関によって構成さ れている。

\section{II. 中国医学科学院医学情報研究所 北京}

この研究所 (以下 IMI と略す) は 1975 年に設立され たものである。職員は 180 名を擁し, そのうち 92 名は 
大学卒業者 (39 名は医科大学出身者)である。管理部門 は別にして，IMI は 2 部門に大別されている。即ち生 物医学情報サービス部門と医学図書館部門である。前 者は更に生物医学情報研究課 ( 3 課), 編集課 ( 2 課), 視聴覚課及び中国生物医学文献の書誌調整課とに細分 されている。生物医学情報研究課は, 外国の図書館の 参考サービスに多少似ているが, 全く同じものとはい 之ない。ここの業務は, 主要な国家的生物医学研究プ ロジェクトや保健衛生研究のみならず，新しい学際的 学問分野における有効な記録情報を提供することにあ る。特定領域に打ける研究の進展具合や傾向に関する クリティカルレビューを作成し, 衛生部 (Ministry of Public Health)や中国医学科学院に提供すると同時 に，わが国の中で，同部門が独自に選択した機関や要 求のあった機関に対しても情報を提供している。主要 な医療従事者に対しては，研究職員が，内外で出版さ れた最新の雑誌や新聞をスクリーニングして必要な文 献を選択, 提供している。彼等は, 生物医学領域の, 全国的，地域的，及び省レベルなどの各種学会にも注 意を払い，議事内容や新知見に関する報告を行ってい る。実に彼等は, 外国製の医療機器の展示会やセミナー に参加したり, 内外の研究者を訪ねて講義を受けたり, 主要な研究プロジェクトの評価などに関与したりして いる。これらの活動を通じて, 彼等は内外の生物医学 研究の先端水準を保っているのである。過去数年間に, 医学の各種領域における貴重な研究成果が参考資料と してまとめられてきている。それらは雑誌の形式で出 版されたり，関係する研究者に直接配布されたりして いる。

以下の定期刊行物は, IMI で編集, 出版されている ものである。

（1）国外医学情報(隔週刊) (Foreign Medical Information)

本誌は, 最新の医学雑誌, 新聞あるいは他の情報提 供機関によって出版された海外の生物医学領域の新知 見, 動向, 理論, 実験などに関する医学記事を収載す るものである。本誌は又海外の著名な研究者による講 演要旨も収載している。年間 624,000 部発行。

(2) 医学研究通訊 (月 刊) (Bulletin of Medical Research)

本誌は, 主として中国医学の研究業績の進展状況, 動向及びレベルなどに関する報告, 各種医学会の話題,
現在及び将来の保健活動に関する提言を含む海外調査 団による報告あるいは診療，研究，教育に関する記事 や中国の生物医学分野の発展に関する概要などを収録 している。年間 168,000 部発行。

(3) 針刺研究 (季刊) (Acupuncture Analgesia)

本誌は，主として鍼療法の臨床応用例，これに伴う 療法の解説をつけた臨床所見や鍼麻酔の作用原理に関 する実験的研究などを収載している。年間 6,400 部発 行。

（4） 医学情報工作 （季刊）（Bulletin of Medical Information Activities)

本誌は, 主として内外の医学図書館, 医学情報活動 の理論，方法，最新技術ならびに動向などを収載する ほか, 地域の医学図書館や情報サ一ビスなどの経験に 基づく報告なども収載している。本誌が，事実上情報 ネットワークの専門誌の役割を担っているといえる。 年間 6,000 部発行。

（5）中文科技資料目録 医学の部(隔月刊) (Index of Chinese Literature on Science and Technology, Section on Medicine)

本誌はわが国の Index Medicus といえる。本誌は, わが国のクリアリング八ウス並びに中央索引部門とし ても機能しているIMIの中国生物医学文献書誌調整 課によって編纂されている。わが国の定期刊行物や学 会で発表された医学及び関連領域の文献を網羅的に収 録している索引誌であり,年間約 27,000 件の文献を処 理している。文献は, アルファベット順主題索引と中 国文献目録規則 (Chinese Literature Cataloguing Rules)に基づいて配列されている。遡及検索の場合に は年間累積版が有効である。年間 6,600 部発行。(なお 1950 年から 1980 年までの累積版は，IMIによるもの ではなく，ある医科大学図書館の手によってまとめら れたものである。)

（6）国外科技資料目録 医学の部 (月刊) (Index of Foreign Literature on Science and Technology, Section on Medicine)

IMI 図書館の索引部門が, 35 の医学図書館の協力の もとに本誌の編纂を行っている。本誌は，5 ケ国語(英 語, フランス語, ドイツ語, 日本語, ロシア語)にわた 
る海外の主要雑誌 520 誌, WHO 出版物及び海外で開 催された医学会の議事録などを収録している。年間 70,000 件が収載され，すべての文献は中国語に翻訳さ れている。索引はアルファベット順主題索引によって いる。

IMI の視聴覚課では, テープ, スライド, ビデオテー プなどを作製するかたわら，希望に応じてそれらの複 製サービスを提供している。

IMI 図書館は 4 部門から成っている。即ち受入, 目 録, 貸出, 索引の 4 部門であり, 職員数は 51 名である。 図書は, 解放された時に 30,000 冊しかなかったもの が, 現在では 150,000 冊にまで増加している。系とじ の普通製本書から木版印刷本や手書きの稀坆本などを 含む中国の医学書が収集されている。雑誌は, 解放時 の 35,000 冊から現在では 250,000 冊までに増加して いる。本年度 (訳者注：会議の行われた時期が 1981 年 12 月なので, 1981 年度のことと思われる。以下同じ。) は 700 種の中国雑誌, 1,751 種の外国雑誌, 合わせて 2 , 451 種の雑誌を購入している。年間に約 6,000 冊の新 着図書が受入, 整理されている。

IMI 図書館は, 中国医学科学院の研究者や関連研究 機関並びに病院に奉仕するだけでなく, 医学図書館 ネットワークを通じて, 国中の専門家にも奉仕してい る。540の図書館との相互貸借サービスも実施してい る。複写サービスは年間 60,000 枚以上提供している。 閲覧者は年間約 65,000 名にも達し, 約 150,000 件の貸 出しを行っている。

\section{III. 生物医学情報ネットワーク活動}

\section{1. 生物医学情報ネットワークの発展}

近年生物医学領域における知識の交流が, わが国と 他国との間で活発に行われている。毎年多くの専門家 が, 学会に出席したり, 留学したり, 調査団に参加し たりするために外国へ派遣されている。同時に海外の 研究者や代表団が, わが国の学術活動に参加するため に招かれている。彼等による技術報告や講演は, 資料 の形式で記録, 処理, 配布されている。この種の文献 (Fugitive Literature訳者注：Grey Literatureと同義) は書誌調整がなされにくいものであるが, 利用者に とっては大変重要な文献である。上海医学情報研究所 (The Shanghai Institute of Medical Information) で
は，定期的にこの種の文献を出版しているが，利用者 には有効なサービスであるといえよう。

中国医学科学院は, わが国における医学研究セン ターであるといえる。医学科学院傘下のほとんどの研 究所や病院は, 専門図書館や情報部門を持っている。 それらは, それぞれの当該領域における学術文献を編 集, 発行, 配布している。各機関は, 非公式ではある が, 当該領域の国立研究センターとして機能している。 IMI は, 資源の分担, 手順の標準化及び情報の研究分 析の協力体制などを確立するために，医学科学院内部 の情報ネットワークを構築するべく多大な努力を払っ ている。

一方地域レベルでは，省(自治区，市)の情報機関や 医科大学図書館を中心にして，ミニネットワークが開 発, 組織化されつつある。シンポジウム, セミナー及 びその他の学術活動が単独で開催されたり, 中国医学 会の地方支部の協力のもとに開催されたりしている。 又講演会が開かれ，生物医学情報の流通に関する経験 が語り合われている。地域的に発行されている出版物 も広く流通していて, 生物医学情報の提供面に有益な 効果をもたらしている。わが国初の地域生物医学情報 ネットワークが, 今年, 中南部地域 ( 5 省, 2 市) で創 設されている。

\section{2. 海外の医学研究に関する情報の提供}

生物医学の全領域を収録している抄録誌, 国外医学 (Foreign Medicine) が, 31 の医科大学及び研究所の協 力によって編集, 発行されている。38 領域に主題区分 された本誌は, 1978 年度の中国医学情報会誐 (National Conference of Medical Information) で承 認された計画に基づいて作成されているものである。 本誌の作成作業は，現在 IMI が調整しつつあり，1982 年度までには主題領域を 40 区分にして発行する予定 である。各領域は, 概ね隔月刊, 月刊もしくは季刊で発 行されている。各号は, レビュー，翻訳文献あるいは 選択された論文の抄録, 会議録及び最新ニュースなど を収載している。この抄録誌によって読者は，常に海 外の生物医学領域の研究及び最新技術を知ることがで きる。年間 10,000 件の論文を収録している本誌は, 一 般によく利用されていて, 総数では $3,000,000$ 部以上 が購読されている。購読者の合計は 492,345 となって いる。中国語と外国語の文献のために 2 種類の索引作 業をするなど，本誌は，異なった医療機関の協力体制 
によって支えられている。

1982 年には, 医学一般, 外科, 産婦人科, 小児科, 中国医学などの領域からなる新しい抄録誌, 中国医学 文献 (Chinese Medical Abstracts)が発行される予定 であり，同時に英語版も，国際的な情報交換促進のた めに編集する計画を進めている。

医学書籍総合目録 (Union Catalogue of Medical Books) 及び外文期刊総合目録 (Union Catalogue of Foreign Periodicals) は数年前に編纂された総合目録 である。マイクロコンピュータが稼動するようになれ ば，これらの総合目録は容易にアップデートなものに なると思われる。本年度は以下の総合目録を編纂する 予定である。即ち, 主要医学機関の所蔵する視聴覚機 器の総合目録, 最新医学研究テーマの総合目録及び省, 市, 自治区における 1980 年度医学研究業績の総合目録 などである。

\section{3. 教育研修}

わが国には, 外国語が使え, しかも正規の教育を受 けた医学図書館員や情報専門家が欠乏している。これ までは, 自己学習と実践活動のみが必要な知識を得る ための主要な手段であった。それ故 IMI は, 短期の外 国語コースを開設したり，医学部の卒業生に高度の教 育を受けさせるために，彼等を特別な研究機関に派遣 したりしてきた。又IMIの職員自身を地方へ派遣して 研修コースを開催したり, 彼等に講義させたりしてき た。例えば，生物医学の主題索引に関する研修コース が, 全国あらゆる地域から 70 名以上の参加を得て, 今 年の夏にハルピンで開催された。1975 年以来, 26 の省 (自治区, 市)で 200 名以上の医学情報従事者が, 何ら かの教育を受けている。その他に 150 名が, 外国の専 門家によって行われている $(\mathrm{a})$ 視聴覚機器の研修コー ス, (b)図書館経営コースなどで現在研修を受けている。 IMI は又, インサービストレーニングの目的で, 図書 館, 情報関係の従事者の受入れを行っている。1980 年 以降既に 12 名が研究調査や留学のために外国へ派遣 され，3名が国際医学図書館員会議及び国際医療情報 科学会議に参加した。

\section{IV. 国 際 協 力}

\section{1. 世界保健機構（WHO）}

WHO と中華人民共和国衛生部との間の合意書が,
1978 年 10 月 5 日に取り交わされ，合意書の実行計画書 も同月中に公表された。双方の文書には，わが国に生 物医学情報センターを設立することが，開発されるべ き優先領域の一つであると述べられている。同時に， WHO が, 全国的医学医療情報, 図書館システムの確立 に関して助言を与えるべきであること,WHOが, 図書 館員の教育及び情報の収集, 分析, 蓄積, 検索, 提供 などの面で援助すべきであること，などが合意されて いる。1979 年 10 月と翌年 8 月に WHO のコンサル夕 ントが, 医学医療情報の施設, サービス内容などを調 查するためにわが国を訪問した。その結果として，こ の分野における今後の開発事項に関する詳細な提案書 が作成された。

WHO 西太平洋事務局 (在マニラ)の調整によって, オフラインの文献検索サービスが, 1981 年に開始され ている。

\section{2. 国連開発計画 (UNDP)}

中華人民共和国政府と国連開発計画との間の合意書 が 1979 年 6 月 29 日に取り交わされ, 害行計画書は 1980 年 7 月 1 日に作成された。この文書には, 生物医学情 報の提供方法の改善, 生物医学系図書館, 情報機関に おける作業効率の向上及びコンピュー夕利用, 要員教 育, 緊急に必要な器材の供給体制の開発などの援助が, わが国に与えられることが述べられている。1980 年 7 月に実施段階に入り，1980１981 年の予備実施期間に 設定された目標は基本的に達成されている。

\section{3. 米国}

医学及び公衆衛生の科学技術協力に関する中華人民 共和国衛生部と米国保健教育福祉省（訳者注 現在は 教育省と保健福祉省に分離) との間の協定書が 1979 年 6 月 22 日に北京において取り交わされた。協定書の付属 文書の中で，両国は以下の点に合意した。(1)医学情報 の交換，(2)中国側が，医学情報処理の近代的な技術に 関する卒後研修を受けるために，技術者を米国に派遣 すること，(3)中国側が，伝統的な中国医学書の目録作 成に関して米国側に援助すること, 以上。なお最後の 項目については今年の 7 月に完了している。

\section{V.おわりに}

中国の 4 つの近代化計画路線において, 生物医学系 
図書館, 情報機関の国家的ネットワークを確立するこ とと同時に，その中核として，強力な国立生物医学情 報センターと豊富な蔵書を有する図書館(Resource Library)を設立させるという緊急な必要性が生じてい る。現在わが国の経済は再編成期にかかっている。こ の時期の終りまでには, 有用な人材や機器を開発して おいて, 生物医学情報ネットワークの安定した基盤を 築き上げておくことが期待されている。政府, 国家科 学技術委員会(National Council of Science and Technology) 及び衛生部などは, すべて図書館, 情報 活動に多大な関心を払っている。中国医学科学院医学 情報研究所の新たな活動の場になると思われる国立医 学図書館, 情報センターを建設するために, 近い将来 政府による予算措置がとられることになっている。

1978 年に行われた中国医学情報会議及び国家医学 図書館会議 (National Medical Library Conference) 以来, 全国的な医学図書館, 情報サ一ビスがかなり進 展してきた。しかしながら, その需要と比較すると, わが国の生物医学情報サービスは未だ初歩的な段階に ある。そのため, 優先順位の高いものから, 順次, 堅 実に開発していくことを心がけねばならない。我々自 身の強化如何によるものではあるが, 我々は他の国, 殊に第三世界の国の，この分野における成功例を学び
とりたいと願っている。又関連する国際機関や国立機 関との接触をより強化したいとも願っている。このよ うな努力を通じて，わが国は，国民の医療保健にとっ てより良いサービスを提供するべく,生物医学図書館, 情報活動を更に改善していくつもりである。WHOの "2000 年までにすべての人に健康を”（Health for All by the Year 2000)という目標や，中国の“2000 年ま でに 4 つの近代化計画の実現を"(Realization of Four Modernization by the Year 2000)という方針などを 具体化していく上でも, 近代的な生物医学情報サービ スの拡充は不可欠である。このように確固たる目標を もって今後の開発計画を推進していくことが何よりも 肝要であろう。

- 脚注：本文は, 1981 年 12 月 14 日 18 日にマニラで開 催された Working Group of Focal Points for the Regional Biomedical Information Programme(主催 WHO 西太平洋事務局)の中で, 中華人民共和国の代表 傅 菜博士(Dr. Richard Frey)の発表した原稿を基 に, WHO 及び同博士の翻訳許可を得た上で,アドバイ ザーとして同会議に出席した訳者が翻訳したものであ る。尚，簡略体文字は編集部で漢字に直した。 